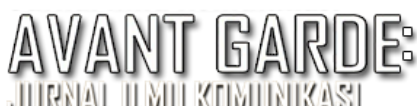

\title{
Bingkai Berita Pencegahan Penyebaran Virus Covid-19 pada Kompas.com dan Detik.com
}

\author{
Aris Sumartono, Ahmad Toni \\ Universitas Budi Luhur \\ J1. Ciledug Raya Petukangan Utara Jakarta Selatan. Indonesia. \\ aris.sumartono@budiluhur.ac.id
}

Submitted: 20 Juni 2021, Revised: 22 September 2021, Accepted: 22 Oktober 2021

\begin{abstract}
Abstrak
Virus Covid-19 telah menyerang secara global atau mendunia, termasuk Indonesia. Virus ini sangat membuat kepanikan dan juga menimbulkan keresahan masyarakat. Keresahan dan kepanikan masyarakat menjadi berlebih dengan adanya pemberitaan terkait Covid-19 yang simpang siur sehingga kebenaran pemberitaan yang disampaikan menjadi sebuah pertanyaan. Dalam hal ini kontribusi media massa ataupun media online sangat diperlukan dalam penyampaian pesan kepada masyarakat agar tidak terjadinya kesalahpahaman dalam menerima sebuah pesan atau berita. Dalam penyampaian sebuah berita, sebuah media harus mempunyai ciri khas tersendiri dalam mengonstruksi pemberitaan. Ciri khas pemberitaan ini dapat dilihat dari gaya penulisan berita yang disampaikan dengan cara membingkai suatu berita biasa dikenal dengan teknik framing berita. Penelitian ini bertujuan memperoleh penggambaran dan analisis media masa online yaitu Detik.com dan Kompas.com dalam pembingkaian berita mengenai pencegahan penyebaran Covid-19 secara online. Pemilihan Detik.com dan Kompas.com dengan pertimbangan karena dianggap media ternama saat ini. Analisis framing yang digunakan ialah model framing Robert N. Entman. Hasil penelitian ini menunjukkan yang membedakan pembingkaian pemberitaan pada Detik.com dan Kompas.com yaitu dalam penyampaian berita. Detik.com secara konstruksi lebih menerapkan konstruksi objektivasi dengan narasi yang lebih umum atau global. Sementara Kompas.com membingkai beritanya dengan menerapkan konstruksi yang eksternalisasi di mana narasi pemberitaannya berisikan curahan hati atau ekspresi pembaca, selain itu penyampaian berita lebih detail dan konkret.
\end{abstract}

Kata kunci: framing, berita COVID-19, media online

\section{News Frame on Prevention of the spread of Covid-19 on Kompas.com and Detik.com}

\begin{abstract}
The Corona virus or Covid-19 has attacked globally or worldwide, including in Indonesia. This virus creates panic and also causes public unrest. The public's anxiety and panic became excessive with the confusing news related to Covid-19 so that the truth of the news conveyed became a question. In this case, the contribution of mass media or online media is very necessary in delivering messages to the public so that there is no misunderstanding in receiving a message or news. In delivering news, a media must have its own characteristics in constructing news. The characteristic of this news can be seen from the writing style of the news that is delivered by framing a news commonly known as news framing technique. The purpose of this study is to get an overview and analyze the understanding of online mass media, namely Detik.com and kompas.com in framing news about preventing the spread of Covid-19 online. The selection of Detik.com and kompas.com with consideration as a leading news portal today. The framing analysis in this study uses the framing model proposed by Robert N. Entman. The results of this study indicate that there are differences in framing news between Detik.com and kompas.com, namely in the delivery of news. Detik.com constructionally applies
\end{abstract}


objectivation construction with a more general or global narrative. While kompas.com framed the news by applying an externalized construction where the narrative of the news contained the outpouring of the heart or the expression of the reader, besides that the news delivery was more detailed and concrete.

Keywords: framing, Covid-19 news, online media

\section{PENDAHULUAN}

Virus korona pada saat ini telah menjadi permasalahan secara global, yang memiliki potensi menyerang kesehatan dan menyebabkan masyarakat panik. Virus yang dikenal dengan nama Covid-19 ini merupakan jenis virus yang bisa menjadi penyebab munculnya beberapa penyakit, misalnya flu hingga $S A R S-C O V$. Virus ini juga dapat menyerang pada binatang misalnya sapi dan babi hingga menyerang pencernaan binatang tersebut, sedangkan jika menyerang unggas virus ini bisa menginfeksi saluran pernapasan sedangkan jika menyerang manusia bisa menyebabkan infeksi saluran nafas dan penyakit lainnya, virus ini ditemukan sejak tahun 1960-an bentuknya seperti paku yang memiliki mahkota (Widiyani, 2020).

Negara-negara lain di dunia bergelut melawan virus Covid-19 hingga saat ini, begitu juga dengan Indonesia. Bertambahnya kasus virus Corona yang terus bertambahnya laporan kesembuhan hingga laporan yang meninggal dunia. Penyebaran virus Corona telah menyebar secara global atau mendunia, termasuk penyebaran di Indonesia. Terutama di wilayah ibu kota sangat membuat kepanikan dan juga menimbulkan keresahan masyarakat. Oleh sebab itu perlu dilakukannya usaha untuk mencegah serta memberantas Covid-19 yang gejalanya mirip dengan penyakit $f l u$.

Salah satu usaha untuk penanganan dan mencegah penyebaran virus Corona ini adalah dengan adanya himbauan dan kebijakan Pemerintah Pusat dalam hal ini dari bapak Presiden Joko Widodo untuk beraktivitas produktif di rumah. Beraktivitas produktif tersebut terkait dengan bekerja biasa disebut dengan istilah work from home, belajar (elearning atau school from home), juga beribadah. Beraktivitas produktif di rumah perlu dilakukan untuk mencegah dan menekan penyebaran virus Corona atau Covid-19.

Sejak diresmikan kebijakan pemerintah untuk beraktivitas produktif di rumah pada tanggal 15 Maret 2020, secara serentak perusahaan-perusahaan baik di bidang pemerintahan, industri, maupun pendidikan langsung meliburkan seluruh karyawannya dan bekerja di rumah dengan mengandalkan teknologi serta jaringan Internet agar tetap dapat produktif bekerja. Termasuk universitas yang ada di Indonesia langsung menanggapi kebijakan pemerintah terkait hal tersebut. Salah satunya dilakukan oleh universitas swasta yang berada di Jakarta yaitu Universitas Budi Luhur. Sebagai bentuk kepedulian Universitas Budi Luhur dalam mendukung pencegahan dan peningkatan penyebaran virus Corona maka Universitas Budi Luhur gencar mengadakan sosialisasi mengenai himbauan pencegahan pandemi virus Corona dan juga sosialisasi mengenai bekerja dan belajar secara produktif sesuai dengan kebijakan Pemerintah melalui media massa maupun media online.

Dalam hal ini kontribusi media massa ataupun media online sangat diperlukan dalam penyampaian pesan kepada masyarakat agar tidak terjadinya kesalahpahaman dalam menerima sebuah pesan atau berita. Kontribusi dari media massa bisa memberikan dampak terhadap isu dan asumsi yang ada pada khalayak, bahwa media bukan hanya sebagai pihak 
yang tidak memihak siapapun bukan justru memilih hal yang dianggap menguntungkan sepihak untuk diangkat ke permkaan, dimana hal ini menyebabkan kerugian bagi pihak lainnya sehingga dapat mendorong khalayak memiliki penafsiran yang berbeda terutama atas suatu pemberitaan hoax yang belum tentu benarnya kebenaran dari data yang didapat. Sebuah persepsi ataupun tanggapan pembaca berita dapat bersifat ambigu dan juga dapat menimbulkan keresahan akibat pemberitaan yang kurang jelas. Reaksi yang diterima pembaca berita dapat bermacam-macam, hal ini berkaitan dengan gaya penulisan berita media massa atau media online.

Pada sebuah media, diketahui adanya gaya ciri khas tersendiri yang dimiliki dalam menyampaikan pemberitaannya. Media bukan saluran yang bisa semaunya melakukan pemberitaan namun pada kenyataannya dapat melakukan kontruksi atas sebuah pemberitaan, kejadian yang sama bisa diberitakan secara berbeda oleh media, sepatutnya dipilih pemberitaan mengenai kejadian yang layak diberitakan ataupun yang seharusnya dihilangkan dengan mengacu pada konsep framing (Mustika, 2017).

Adapun yang diartikan sebagai framing ialah kejadian yang diberitakan pada media yang menggarisbawahi bagian khusus dan menonjolkan sisi tertentu yang dipilih dengan bahasa yang dibuat seakan heboh sehingga kejadian tersebut dapat diketahui dan mudah melekat pada ingatan masyarakat (Eriyanto, 2002). Teori framing banyak digunakan oleh para peneliti dalam menemukan gaya media online dalam membingkai sebuah berita. Ayub Dwi Anggoro dalam penelitiannya yang berjudul "Analisis Framing Model Robert N. Entman tentang pemberitaan hasil pemilihan Presiden”, 9 Juli 2014 di TV One dan Metro TV" (Anggoro, 2019) menunjukkan bahwa keseimbangan dan netralnya sebuah pemberitaan media sudah tidak lagi ditemukan dalam tayangan pemilu yang terjadi di tahun 2014 sehingga orientasinya berubah dan mengacu pada nilai bisnis semata bukan lagi konsep politik yang ditekankan.

Penelitian dengan judul "Analisis Framing Pemberitaan Media Online Mengenai Kasus Pedofilia Di Akun Facebook” oleh Rieke Mustika (Mustika, 2017) mengemukakan hasil penelitiannya menunjukkan bahwa terdapatnya hal yang berbeda antara dua media online yaitu Kompas dan Republika dalam hal pemilihan narasumbernya satu sama lain.

Di sisi lain, Azwar Marzuki dan Kahar (Komunikasi et al., 2016) mengemukakan hasil penelitiannya yang berjudul "Analisis Framing Rubrik Laporan Utama Tabloid Verbeek" menunjukkan jika konsep framing yang dibangun dalam berita yang ada pada tabloid Veerbeek diterapkan unsur yang mengesankan kuatnya pengaruh dampak dari program sosial PT Vale untuk khalayak

Penelitian yang berjudul "Kepemilikan Dan Bingkai Media (Analisis Framing Pemberitaan Joko Widodo Sebagai Kandidat Calon Presiden Pada Koran Sindo)" (Kurniasari \& Aji, 2018) menyebutkan jika pemberitaan mengenai calon presiden pada tiap media memiliki sudut pandang yang berlainan dari segi ide pikiran yang dikembangkan, hasil penelitian menunjukkan bahwa sebenarnya media tidak dapat menjadi cerminan atas kenyataan yang sebenarnya terjadi karena dipengaruhi oleh sejumlah faktor sehingga berlainan dengan fakta di lapangan.

Begitu juga dengan penelitian yang dilakukan oleh Rebecca Santosa (Santosa, 2016) dengan judul "Analisis Framing Pemberitaan Etnis Tionghoa dalam media online Republika 
di bulan Februari 2016", menunjukkan bahwa Republika memberitakan mengenai masyarakat Tionghoa melalui konsep agama Islam yang memperlihatkan sisi kemajemukan dan dapat menghargai satu dan lainnya ketika upacara imlek dilaksanakan.

Berdasarkan penelitian terdahulu, untuk membahas mengenai perbandingan dua media dalam membingkai berita tentang Universitas Budi Luhur dalam menanggapi virus Korona digunakan framing model Robert N. Entman yang menggarisbawahi pemikiran tentang sudut pandang atas sebuah pemberitaan.

Selain itu juga akan dilihat bagaimana kedua media online tersebut sebagai sebuah realitas yang dianggap hasil perekonstruksian, analisis ini juga mengamati mengenai teks berita yang dimuat, sebagaimana pendapat Berger dan Luckman (Berger, n.d.), media dengan tiga tahapan yaitu eksternalisasim, objektivasi, dan internalisasi. Dimana dalam perspektif wartawan terhadap sesuatu hal. Media mempunyai gaya penulisan yang menggambarkan kejadian tersebut. Frame memperlihatkan bagaimana kenyataan tersebut diambil untuk diaplikasikan menjadi pemberitaan website.

Dengan demikian suatu penelitian diperlukan untuk melihat sejauh mana media online membingkai pemberitaan tentang Universitas Budi Luhur menanggapi virus Corona melalui penggunaan teori Framing Robert N. Entman dengan objek penelitian Detik.com, dan Kompas.com.

\section{METODE PENELITIAN}

Pendekatan yang digunakan pada penelitian ini ialah kualitatif, yang ditujukan untuk memperoleh gambaran dalam mengartikan kenyataan fenomena yang menjadi objek diteliti melalui pendekatan secara keseluruhan yang berdasarkan fakta. Penelitian ini menggunakan metode framing, yang ditujukan untuk menganalisis frame atau package dari sebuah media yang dijadikan objek penelitian mengenai kenyataan yang terjadi di masyarakat(Bungin, S.Sos, 2017) .

Menurut Entman, bahwa analisis bingkai pada pemberitaan memiliki empat cara, yaitu:

1. melaksanakan identifikasi dari permasalahan

2. menemukan sebab dari masalah

3. menjalankan evaluasi moral

4. memberikan saran penanggungan masalah

Model dalam analisis framing yang digunakan dari Robert N. Entman. Subjek penelitian merupakan tempat dimana variabel didapatkan (Arikunto, 2010). Adapun dalam penelitian ini subjeknya ialah Universitas Budi Luhur. Kemudian yang menjadi objek penelitian ialah sesuatu yang dijadikan sasaran penelitian dari subjek, benda maupun aktivitas khusus untuk diambil kesimpulannya (Sugiyono, 2013). Dalam kajian ini yang menjadi objek ialah Detik.com dan Kompas.com. hal ini dilakukan karena kedua objek tersebut menjadi media pertama dan sering mempublikasikan Universitas Budi Luhur dalam menanggapi pandemi Covid-19.

Teknik pengumpulan data yang digunakan dalam penelitian ini adalah wawancara untuk mengetahui persepsi dan pandangan pimpinan Universitas Budi Luhur atas keberadaan pandemi ini, observasi yaitu observasi pra-penelitian guna mengetahui sejauh mana peranan 
kampus dalam menghadapi wabah tersebut. Selain itu observasi dilaksanakan terhadap berita yang berkaitan dengan fokus penelitian, studi pustaka dilaksnakaan dengan pengumpulan informasi pada sumber-sumber kajian yang memiliki keterkaitan.

Tekhnik menganalisis data dilaksanakan secara reduksi data yaitu dengan cara mengumpulkan berita-berita terkait dengan topik virus Corona (Covid-19) dimulai dari awal mula munculnya virus tersebut hingga penyebarannya di dunia sampai dengan ke Indonesia. Setelah mendapatkan berita tentang virus Corona (Covid-19) di Indonesia, kemudian diseleksi lagi untuk mendapatkan berita korona dengan topik cara pencegahan dan penerapan work from home dan penerapan perkuliahan jarak jauh di perguruan tinggi. Langkah selanjutnya menyeleksi dan mempersempit pemberitaan khusus di Universitas Budi Luhur, selanjutnya triangulasi yang melibatkan observasi, wawancara dan dokumentasi. Teknik analisis data diakhiri dengan melakukan anlisis dan menarik kesimpulan.

\section{HASIL DAN PEMBAHASAN}

Pemberitaan yang dijadikan objek penelitian tentang Corona atau Covid-19 pada media online Detik.com terdiri dari tiga judul berita, yaitu pemberitaan yang pertama berjudul "Penyebab, Asal Mula, dan Pencegahan Virus Corona di Indonesia" (Niken Widya Yunita - detikNews, 2020). Pemberitaan yang kedua berjudul "Kerja di Rumah Saja Bikin Volume Kendaraan Berkurang di Ibu Kota" (Tim detikcom - detikNews, 2020a), dan pemberitaan yang ketiga berjudul "Langkah Universitas Antisipasi Persebaran Corona Jadi Terbatas" (Tim detikcom - detikNews, 2020b).

Sedangkan berita pada media online Kompas.com juga terdiri tiga judul berita yaitu pemberitaan yang pertama berjudul "Virus Corona: Penyebab, Gejala, Pencegahan, dan Kapan Harus Segera ke Dokter" (Azanella \& Nugroho, 2020). Pemberitaan yang kedua berjudul "Kebijakan Kerja dari Rumah Positif untuk Pegawai dan Perusahaan" (Sakina Rakhma Diah Setiawan, 2020), dan pemberitaan yang ketiga berjudul "LLDIKTI Tetap Pantau Kegiatan Kampus Selama Pandemi Covid-19” (Harususilo, Yohanes Enggar Harususilo, 2020).

Adapun pemilihan judul berita didasarkan pada 3 kategori yaitu pemberitaan dengan judul terkait asal mula virus korona atau virus Covid-19, pemberitaan dengan judul terkait kebijakan instansi dan pemerintah sebagai solusi dalam menghadapi kondisi pandemi Covid19, dan pemberitaan dengan judul tentang tindakan aktiviitas yang tetap berlangsung ditengah keberadaan wabah.

Hasil pemberitaan tersebut dianalisis secara bertahap yaitu pada langkah awal akan dilakukan analisis teks terhadap pemberitaan tersebut secara keseluruhan, di mana analisis teks ini menggunakan teori analisis framming dengan model Robert N. Entman, kemudian dilanjutkan dengan melakukan analisis konstruksi sosial.

Analisis teks yaitu suatu aktivitas menganalisis data teks seperti berita, email, blog, tweet, forum dan bentuk lainnya. Dalam penelitian ini analisis teks dilakukan dengan menggunakan berita Detik.com, dan Kompas.com, dengan topik pembahasan mengenai pemberitaan pencegahan penyebaran virus Covid-19. Analisis teks Robert N. Entman, yang fokus pada kajian pemberian pengertian,kejelasan dan mengevaluasi atau merekomendasikan suatu wacana atas sebuah kerangka pemikiran kejadian dalam sebuah wacana. 
Analisis akan dilakukan terhadap media massa online terkait pemberitaan mengenai virus Covid-19 dengan empat variabel yang terdapat pada tabel model Entman. Berikut ini analisis framing pemberitaan menggunakan konsep Entman.

Tabel 1 Analisis Framing 1

Pemberitaan terkait asal mula virus korona atau virus Covid-19

\begin{tabular}{|c|c|c|}
\hline \multirow[b]{2}{*}{ Variabel model Entman } & \multicolumn{2}{|l|}{ Pemberitaan mengenai: } \\
\hline & $\begin{array}{l}\text { Penyebab, Asal Mula, dan } \\
\text { Pencegahan Virus Korona di } \\
\text { Indonesia } \\
\text { (Sumber: Detik.com) }\end{array}$ & $\begin{array}{l}\text { Virus Korona: Penyebab, Gejala, } \\
\text { cara mencegah dan waktu yang tepat } \\
\text { mengunjungi dokter } \\
\text { (Sumber: Kompas.com) }\end{array}$ \\
\hline $\begin{array}{l}\text { Define Problems } \\
\text { Bagaimana suatu peristiwa/ } \\
\text { isu dilihat? Sebagai apa? Atau } \\
\text { sebagai masalah apa? } \\
\text { Apa yang jadi masalah? }\end{array}$ & $\begin{array}{l}\text { Informasi mengenai asal mula virus } \\
\text { korona, penularannya dan } \\
\text { pencegahan mandiri secara umum. }\end{array}$ & $\begin{array}{l}\text { Permasalahannya adalah ketidaktahuan } \\
\text { informasi tentang Covid-19 seringkali } \\
\text { menimbulkan ketakutan dan kepanikan } \\
\text { yang berlebih di tengah masyarakat. } \\
\text { Sebuah informasi terkait dengan } \\
\text { pengertian virus Covid-19, gejala dan } \\
\text { berbgai pertanyaan terkat virus Covid- } \\
19 \text {. }\end{array}$ \\
\hline $\begin{array}{l}\text { Diagnose causes } \\
\text { (Memperkirakan masalah } \\
\text { atau sumber masalah) } \\
\text { Apa penyebabnya? }\end{array}$ & $\begin{array}{l}\text { Virus korona atau Covid-19 yang } \\
\text { menyebabkan korban jiwa maupun } \\
\text { warga yang dinyatakan positif. }\end{array}$ & $\begin{array}{l}\text { Ketidaktahuan warga mengenai virus } \\
\text { Covid-19 serta saran pencegahan } \\
\text { menurut WHO. }\end{array}$ \\
\hline $\begin{array}{l}\text { Make moral judgement } \\
\text { (Membuat keputusan moral) }\end{array}$ & $\begin{array}{l}\text { Tiap individu mengambil langkah } \\
\text { untuk turut memberantas mata } \\
\text { rantai tersebarnya virus covid-19 }\end{array}$ & $\begin{array}{l}\text { Covid-19 bisa sembuh dan pulih total } \\
\text { berdasarkan daya imun individu dengan } \\
\text { mengikuti tahap untuk mencegah } \\
\text { penyebarannya }\end{array}$ \\
\hline $\begin{array}{l}\text { Treatment Recommendation } \\
\text { (Menekankan penyelesaian) } \\
\text { Saran/Solusi }\end{array}$ & $\begin{array}{l}\text { Yuri (Juru Bicara Pemerintah } \\
\text { dalam Penanganan Virus Korona) } \\
\text { Memberikan himbauan bagi } \\
\text { khalayak supaya selalu mencuci } \\
\text { tangan dalam segala aktivitasnya }\end{array}$ & $\begin{array}{l}\text { Mengambil keterangan dari The } \\
\text { Guardian tentang urgensi mengetahui } \\
\text { virus ini dengan seksama agar dapat } \\
\text { menghindari untuk tidak tertular dan } \\
\text { meredam keadaan rasa takut dan panik }\end{array}$ \\
\hline
\end{tabular}

Sumber: Hasil Penelitian, 2015

Tabel 2 Analisis Framing 2

Pemberitaan terkait kebijakan intansi dan pemerintah sebagai solusi dalam menghadapi kondisi pandemi Covid-19

\section{Variabel model Entman}

Define Problems

Bagaimana suatu peristiwa/ isu dilihat? Sebagai apa? Atau sebagai masalah apa? Apa yang jadi masalah?

\section{Pemberitaan mengenai:}

Melakukan pekerjaan di rumah sehingga jumlah kendaraan yang beraktivitas dapat dikurangi (Sumber: Detik.com)

Anjuran untuk berdiam diri di dalam tempat tinggal yang berdampak pada menurunnya laju gerak kendaraan ibukota

\section{Kebijakan Kerja dari Rumah Positif} untuk Pegawai dan Perusahaan (Sumber: Kompas.com)

Menurut Priyantono Rudito, seorang pakar sumber daya manusia (SDM) dan Andre Soelistyo, Co-CEO Gojek menilai kebijaksanaan Work From Home (WFH) merupakan hal yang tepat di masa pandemi virus korona, dan dilakukan demi keselamatan dan kesehatan.

Penyebaran atau menularnya virus

korona.

$\begin{array}{ll}\text { Diagnose causes } & \text { Perintah bekerja dari rumah atau } \\ \text { (Menganalisis masalah serta } & \begin{array}{l}\text { yang dikenal dengan WFH dari } \\ \text { Presiden yang juga diarahkan oleh }\end{array} \\ \text { Apmernya) } & \text { Gubernur Jakarta }\end{array}$

Diagnose causes Perintah bekerja dari rumah atau

Apa penyebabnya?

Make moral judgement $\quad$ Selama berlakunya WFH volume Beberapa lembaga dan swasta




\begin{tabular}{lll}
\hline (Membuat keputusan moral) & $\begin{array}{l}\text { kendaraan di jalur protokol } \\
\text { mengalami penurunan yang cukup } \\
\text { signifikan. }\end{array}$ & $\begin{array}{l}\text { memerintahkan pegawainya untuk } \\
\text { menerapkan bekerja dari rumah }\end{array}$ \\
\hline $\begin{array}{l}\text { Treatment Recommendation } \\
\text { (Menekankan penyelesaian) }\end{array}$ & $\begin{array}{l}\text { Pemerintah masih terus } \\
\text { menyerukan WFH dan juga jaga agar tetap dapat bekerja dan produktif }\end{array}$ & $\begin{array}{l}\text { WFH merupkan penyelesaian masalah } \\
\text { Saran/Solusi }\end{array}$ \\
& $\begin{array}{l}\text { jarak aman dalam komunikasi di tengah keberadaan virus. } \\
\text { sosial agar risiko penularan virus } \\
\text { korona ini tidak semakin menjadi- }\end{array}$ \\
& jadi.
\end{tabular}

Sumber: Hasil Penelitian, 2015

Tabel 3 Analisis Framing 3

Pemberitaan terkait tindakan atau langkah yang dilakukan agar aktifitas kerja dapat tetap berjalan meskipun dalam kondisi pandemic Covid-19.

\section{Pemberitaan mengenai:}

\section{Variabel model Entman}

Define Problems

Bagaimana suatu fenomena dilihat? Sebagai permasalahan atau apa?

Apa permasalahannya?

Diagnose causes

(menganalisis masalah dan Covid-19 dan penyebarannya sumbernya)

Apa penyebabnya?

Make moral judgement

(Membuat keputusan moral) 19.

\section{Langkah Universitas Antisipasi LLDikti Tetap Pantau Kegiatan Persebaran Korona Jadi Kampus Selama Pandemi Covid-19 Terbatas (Sumber: Detik.com) (Sumber: Kompas.com)}

Sejumlah ide dijalankan perguruan LLDIKTI mengawasi dan memonitor tinggi untuk mengantisipasi dalam sejumlah aktivitas perguruan penyebaran virus pandemi Covid- tinggi yang berlangsung secara online selama pandemi

Melakukan monitor dan evaluasi (Monev) melalui online tentang usaha yang ditempuh universitas selama pandemi

Melakukan kegiatan kuliah jarak jauh dan menunda segala aktivitas wisuda untuk mencegah tersebarnya virus semakin tinggi
Adanya langkah konkret dari beberapa Perguruan Tinggi dalam menurunkan angka penyebaran covid-19 berupa perkuliahan jarak jauh, pemberian kuota gratis untuk mahasiswa, memproduksi disinfektan dan hand sanitizer, platform pembelajaran, donasi Rp. 1 Milyar, mahasiswa menjadi relawan, serta pembuatan masker dan baju hazmat untu tenaga medis.

Menurut Plt. Kepala/Sekretaris LLDIKTI Wilayah III, Samsuri,

Pimpinan civitas akademika diberikan kebebasan untuk mengambil keputusan yang dinilai sesuai dengan keadaan universitasnya

Sumber: Hasil Penelitian, 2015

UI, UINSA, UNY dan UGM melakukan Perkuliahan Jarak Jauh (PJJ), kegiatan akademik dan kegiatan administrasi secara daring.
Menekankan penyelesaian)

Saran/Solusi

Hasil analisis framing pada pemberitaan online Detik.com adalah sebagai berikut:

Framing pertama Detik.com pada tanggal Sabtu, 28 Maret 2020 yang berjudul "Penyebab, Asal Mula, dan Pencegahan Virus Corona di Indonesia" (Niken Widya Yunita detikNews, 2020), berita ini menceritakan kronologi awal mulanya pada penghujung 2019 virus korona atau Covid-19 berada di wilayah China dan ditemukannya di Indonesia di awal 2020 dengan data per 28 Maret 2020 menyerang hingga 1.155 orang dan yang meninggal sebanyak 102 jiwa. Dari awal Maret hingga akhir Maret 2020 penyebaran virus ini sangat cepat. 
Berita ini juga menekankan anjuran pemerintah agar masyarakat menjaga jarak sosial, hal ini dikarenakan meningkatnya jumlah kasus positif Corona di Indonesia yang disebabkan oleh penularan di luar rumah. Selanjutnya berita ini menjelaskan mengenai penularan virus Corona melalui lendir/cipratan (droplet) manusia seperti batuknya orang terjangkit Corona atau Covid-19. Selain itu pencegahan penyebaran virus Corona secara mandiri juga diuraikan menekan penyebaran Covid-19.

Narasi yang disampaikan oleh Detik.com mengenai himbauan dari Pemerintah pada masyarakat agar menetap di kediaman melakukan social distancing, memperhatikan kebersihan, mencuci kedua tangan dan diberlakukannya kegiatan bekerja dari rumah (work from home). Disampaikan Yuri, kerumunan di luar rumah inilah yang meninggikan angka Corona covid-19

Framing kedua Detik.com yang berjudul "Kerja di rumah dapat mengurangi jumlah volume kendaraan berkurang di Ibu Kota" (Tim detikcom - detikNews, 2020a) pada tanggal 28 Maret 2020, berita ini ditulis oleh tim Detik.com. Berita ini terdiri dari lima belas paragraf dan mempunyai alur cerita yang diawali dengan himbauan agar berdiam diri di kediaman yang berpengaruh pada penurunan laju kendaraan di ibukota

Mulai paragraf dua hingga paragraf tujuh pada pemberitaan ini, justru menceritakan mengenai anjuran bekerja dari rumah work from home (WFH) seperti arahan Presiden Joko Widodo. Himbauan tersebut berupa perintah untuk mengerjakan aktivitas di kediaman dengan menjaga jarak sosial.

Alur cerita dari pemberitaan ini yang merepresentasikan judul berita dapat diketahui mulai dari paragraf ke delapan hingga terakhir. Kepala Subdirektorat Penegakan Hukum pada Ditlantas Polda Metro Jaya, AKBP Fahri Siregar selaku pada hari Jumat, 23 Maret 2020, menyatakan bahwa selama berlakunya WFH volume kendaraan di jalur protokol mengalami penurunan yang cukup signifikan. Tercatat setidaknya ada 289.734 kendaraan bermotor melintas pada jalur protokol Sudirman-Thamrin dari arah selatan menuju ke utara pada periode 15 Maret hingga 21 Maret 2020. Periode itu terhitung sejak mulai diberlakukannya WFH di bilangan Jakarta. Jumlah itu terhitung relatif lebih rendah dibandingkan periode sebelum WFH diberlakukan yaitu setidaknya pada 8 Maret sampai 14 Maret 2020. Dalam periode itu tercatat volume kendaraan bermotor yang melintas di ruas jalan yang sama yaitu 387.935 .

Dengan adanya himbauan Pemerintah untuk terus menyerukan WFH dan juga jaga jarak aman dalam komunikasi sosial agar risiko penularan virus Corona ini tidak semakin menjadi-jadi, merupakan solusi menurunkan volume kendaraan di Ibu Kota.

Framing ketiga situs Detik.com pada pemberitaan yang berjudul "Langkah Universitas Antisipasi Persebaran Corona Jadi Terbatas" (Tim detikcom - detikNews, 2020b), yang ditulis oleh tim Detik.com pada tanggal 15 Maret 2020. Berita ini menyoroti tentang langkah-langkah yang diambil oleh beberapa Universitas untuk membatasi persebaran Covid-19. Pemberitaan ini terdiri dari tujuh paragraf yang terdiri dari prolog dan isi, tanpa adanya penutup dalam narasi berita ini. Pada paragraf pertama sudah cukup jelas menerangkan apa yang jadi pemberitaan atau apa masalah dalam berita ini.

Situs berita Detik.com melaporkan bahwa beberapa Universitas sudah menerapkan Perkuliahan Jarak Jauh (PJJ) dalam rangka menekan persebaran virus ini yang dimuat pada 
paragraf ke dua hingga ke tujuh, Universitas Indonesia (UI) menerapkan sistem belajar jarak jauh (PJJ) dari sejak18 Maret 2020 sampai akhir genap tahun akademik 2019/2020. Namun UI masih memperbolehkan KBM dalam bentuk praktik asal memenuhi ketentuan untuk berusaha menekan tersebarnya virus, UI memberikan himbauannya pada mahasiswa perantauan untuk pulang ke kampung halaman, hal ini sejalan dengan apa yang diterapkan oleh Universitas Islam Negeri Sunan Ampel (UINSA) dengan meliburkan kuliah sejak 16-20 Maret 2020, namun metode yang digunakan tidak dijelaskan. Universitas Negeri Yogyakarta (UNY) mengeluarkan instruksi kegiatan pembelajaran, layanan akademik, dan layanan umum dari jenjang diploma hingga S3 dilakukan secara daring (online). Di sisi lain, Universitas Gajah Mada (UGM) menggelar perkuliahan secara online, Pemberitaan di situs Detik.com tidak ditemukannya narasi berupa kalimat penutup ataupun kesimpulan dari pemberitaan tersebut.

Hasil Analisis Framing pada pemberitaan online Kompas.com adalah sebagai berikut: Framing pertama Kompas.com pada hari Selasa tanggal 31 Maret 2020 yang berjudul: "Virus Corona: Penyebab, Gejala, Pencegahan, dan Kapan Harus Segera ke Dokter" (Azanella \& Nugroho, 2020), ditulis oleh Luthfia Ayu Azanella. Berita ini terdiri dari 8 paragraf, yang terdiri dari prolog, isi, dan juga penutup. Kompas.com berusaha menginfokan pemberitaan mengenai virus korona dengan maksud agar masyarakat lebih memahami mengenai virus korona agar tidak menimbulkan ketakutan dan kepanikan yang berlebih.

Adapun kronologi pemberitaan ini dimulai dari sebuah prolog atau kata pengantar di awal paragraf yang dilanjutkan dengan pertanyaan mengenai virus dari gejalanya, kapan saatnya ke dokter, jumlah korban yang sudah terinfeksi, perbandingan dengan virus influenza, yang diakhiri dengan saran pencegahan dari WHO. Situs berita Kompas.com dalam pemberitaannya berusaha membuat perkiraan pertanyaan-pertanyaan yang mungkin akan ditanyakan oleh masyarakat terkait dengan virus korona atau Covid-19. Pertanyaan tersebut langsung diuraikan jawabannya berupa narasi dan diakhiri dengan saran pencegahan penyebaran virus korona oleh WHO.

Framing kedua dalam pemberitaan Kompas.com yang berjudul:"Kebijakan Kerja dari Rumah Positif untuk Pegawai dan Perusahaan" (Sakina Rakhma Diah Setiawan, 2020), pemberitaan ini ditulis oleh tim Kompas.com per 18 Maret 2020. Berita ini menyampaikan anjuran untuk WFH (work from home) sebagai solusi dari Pemerintah. Sehingga bisa mengurangi risiko tersebarnya virus ini. Menurut Priyantono Rudito seorang pakar sumber daya manusia (SDM), menyatakan sebelum berlangsungnya keadaan ini, WFH sudah menjadi langkah dari tren \& outlook HR practices.

Bagi karyawan, kegiatan WFH bisa menjadi alternatif jalan keluar untuk menyeimbangi kegiatan bekerja dan kehidupan individu, Untuk perusahaan, kegiatan WFH mulai diterapkan untuk memberikan dukungan mengenai penyelesaian pekerjaan dengan koloborasi yang baik, Priyantono memberikan ungkapan jika pada sejumlah perusahaan ini menjadi langkah yang baik untuk bertransformasi di era digital, pemberitaan ini juga menyebutkan Gojek adalah salah satu perusahaan yang menerapkan WFH di sejumlah negara dan akan diterapkan pada minggu ini. Berdasarkan pemberitaan Kompas.com ini dapat disimpulkan bahwa kebijakan work from home berdampak positif untuk menekan dan meminimalisir risiko penyebaran pandemi. 
Framing ketiga Kompas.com pada tanggal Selasa, 7 April 2020 yang berjudul: "LLDIKTI Tetap Pantau Kegiatan Kampus Selama Pandemi Covid-19" (Harususilo, Yohanes Enggar Harususilo, 2020), ditulis oleh Yohanes Enggar Harususilo. Berita ini menginfokan dan berusaha meyakinkan masyarakat bahwa meskipun diberlakukan kebijakan WFH, LLDIKTI tetap menjalankan tugasnya untuk melakukan pengawasan kepada Perguruan Tinggi di kopertis wilayah III terkait kegiatan Tridarma Perguruan Tinggi. Pengawasan dilakukan dengan cara video conference dengan sejumlah tema yang diangkat dalam kurun waktu satu kali dalam 2 minggu bersama 20 orang pimpinan universitas. Menurut Samsuri, Plt. Kepala/Sekretaris LLDIKTI Wilayah III mengatakan bahwa kegiatan tersebut merupakan bagian dari memonitor dan mengevaluasi usaha yang dilaksanakan Universitas selama adanya virus ini, dari kegiatan pemeblajaran yang diubah hingga bentuk pengabdian di tengah khalayak

Berdasarkan pemberitaan Kompas.com ini dapat diketahui bahwa beberapa Perguruan Tinggi di kopertis wilayah III memberikan pengaruhnya untuk membantu menekan keberadaan virus dengan pelaksanaan bekerja dan kuliah dari rumah, Berdasarkan kontribusi tersebut, Samsuri memberikan apresiasinya. Adapun langkah konkret dari beberapa Perguruan Tinggi memberikan kontribusi kepada Pemerintah dalam penekanan jumlah penyebaran Covid-19 berupa perkuliahan jarak jauh, pemberian kuota gratis untuk mahasiswa, memproduksi disinfektan dan hand sanitizer, platform pembelajaran, donasi Rp. 1 Milyar, mahasiswa menjadi relawan, serta pembuatan masker dan baju hazmat untuk tenaga medis. Perguruan Tinggi yang berkontribusi antara lain Universitas Bina Nusantara, Universitas Katolik Indonesia Atma Jaya, Universitas Gunadarma, Universitas Tarumanagara, Universitas Muhammadiyah Prof. Dr. Hamka, Akademik Keperawatan RSPAD Gatot Subroto, dan Universitas Budi Luhur.

Menurut Samsuri, aktivitas relawan yang dilaksanakan mahasiswa diagendakan ke dalam aktivitas Kuliah Kerja Nyata/KKN asal sesuai dengan ilmu yang ditekuni, disetarakannya kegiatan ini dimasukkan dalam program kurikulum kampus, LLDikti Wilayah III juga melaksanakan video conference series yang memberikan manfaat dengan melibatkan perguruan tinggi dan turut mengundang pejabat di lingkungan Kemendikbud. Kegiatan tersebut antara lain; Bincang-bincang penelitian dan pengabdian masyarakat selama pandemi COVID-19, Pembahasan tentang Akreditasi Perguruan Tinggi, Transformasi beasiswa BIDIKMISI menjadi KIP Kuliah, Sosialisasi Aplikasi Jenjang Jabatan Akademik Dosen "SIJALI3", INOVASI Perguruan Tinggi, dan sebagainya.

Perbedaan Frame pemberitaan online Detik.com dan pemberitaan online Kompas.com dalam pemberitaan terkait Pencegahan Penyebaran Virus Covid-19. Pemberitaan yang diangkat Detik.com dan Kompas.com tidak lepas dari rekonstruksi, berdasarkan teori konstruksi realitas sosial mengenai realitas yang dianggap sebagai sebuah hasil dari konstruksi, analisis framing masuk ke dalam paradigrma konstruksi dimana pandangannya fokus pada berita dan teks yang dimuat. Menurut Berger dan Luckman (Berger, n.d.), tiga ttahapan yang ditempuh media ialah eksternalisasim, objektivasi, dan internalisasi. Proses ini merupakan bagaimana sudut pandang wartawan terhadap sesuatu hal. Media mempunyai wacananya sendiri dalam mengambil sudut pandang atas sebuah 
fenomena. Frame menentukan seperti apa kenyataan diangkat dan bagaimana hasil data yang diperoleh dimuat dalam satu pemberitaan online.

Jika dilihat dari analisis framing, Detik.com mempresentasikan pemberitaan berdasar pada realita secara umum atau global. Secara konstruksi, Detik.com lebih menerapkan konstruksi objektivasi di mana tata bahasa yang dimunculkan berupa hasil yang telah dicapai. Sebagai contoh pada kalimat"virus corona menyebabkan korban jiwa yang dinyatakan positif", dalam kalimat ini ada kata "menyebabkan" yang merupakan hasil dari proses terjangkitnya masyarakat terhadap virus Corona. Begitu juga pada kalimat"setiap warga berperan memutus mata rantai penyebaran virus corona".

Berdasarkan analisis framing pemberitaan Kompas.com berdasar kenyataan lapangan, Secara konstruksi, Kompas.com lebih menerapkan konstruksi eksternalisasi di mana terdapatnya raut ekspresi individu yang diberitakan. Hal ini terlihat dari hasil analisis framing di mana penggunaan kata"masyarakat merasakan" serta penjelasan akan suatu hal lebih detail dan konkret disertai dengan contoh, seperti halnya penjelasan mengenai seperti apa gejala virus ini, cara pencegahan penyebarannya pun dijelaskan mendetail.

Baik Detik.com maupun Kompas.com, menunjukkan keberadaanya pada pihak tertentu, Kompas.com lebih mengarah pada penyeimbangan berita dengan pemberian kesempatan seluruh pihak untuk menyatakan pendapat, Detik.com maupun Kompas.com melakukan pemilihan narasumbernya pada tokoh pejabat mengenai penanganan dan upaya menekan angka covid-19. Dalam memilih judul, orang yang hendak ditanya dan pengangkatan isu dari kedua media hampir sama yang membuat pembaca sudah dapat memprediksi kisi dari pemberitaan. Pada prinsipnya, Detik.com dan Kompas.com memiliki latar belakang ideologi yang sama, yaitu ideologi humanisme yang selalu mengedepankan prinsip-prinsip kemanusiaan.

\section{SIMPULAN}

Kesimpulan yang dirumuskan dari hasil analisis bahwa terdapatnya perbedaan pembingkaian pemberitaan pada Detik.com dan Kompas.com, dimana situs berita Detik.com secara konstruksi lebih menerapkan konstruksi objektivasi dengan narasi yang lebih umum atau global. Sementara Kompas.com membingkai beritanya dengan menerapkan konstruksi yang eksternalisasi di mana narasi pemberitaannya berisikan curahan hari atau ekspresi pembaca, selain itu penyampaian berita lebih detail dan konkret.

Sudut pandang wartawan dalam mencari dan menulis berita sebaiknya memperhatikan ke 3 elemen dalam konstruksi realitas sosial, yaitu eksternalisasi, objektivasi, dan internalisasi. Selain itu penyampaian berita sebaiknya dapat lebih detail dan konkret sehingga pemahaman pembaca akan lebih baik lagi dan tidak menimbulkan pemahaman yang kurang.

\section{UCAPAN TERIMA KASIH}

Penulis mengucapkan puji syukur kehadirat Allah SWT, Rasulullah SAW dan para sahabatnya, keluarga tercinta, Civitas akademika Universitas Budi Luhur yang telah memberikan sumbangsih untuk menyelesaikan artikel ini. Terimakasih yang sebesarbesarnya bagi seluruh pihak di Jurnal Avant Garde yang telah memberi kesempatan untuk 
menyajikan artikel ini, dan kepada reviewer yang telah banyak memberikan masukan untuk memperbaiki artikel ini.

\section{DAFTAR PUSTAKA}

Anggoro, A. D. (2019). Media, Politik dan Kekuasaan (Analisis Framing Model Robert N. Entman tentang pemberitaan hasil pemilihan Presiden, 9 Juli 2014 di TV One dan Metro TV). Aristo, 2(2), 25-52.

Arikunto, S. (2010). Prosedur Penelitian: Suatu Pendekatan Praktik. Jakarta, Indonesia: Rineka Cipta.

Berger, P. L. (n.d.). and Thomas Luckmann The Social Construction of Reality Treatise in the Sociology.

Eriyanto. (2002). Analisis framing: konstruksi, ideologi, dan politik media. Yogyakarta, Indonesia: Yogyakarta : LKiS, 2002.

Komunikasi, I., Ilmu, F., Dan, S., Politik, I., Hasanuddin, U., Timur, L., \& Massa, M. (2016). Azwar Marzuki , Kahar, 5(2), 406-430.

Kurniasari, N., \& Aji, G. G. (2018). Kepemilikan Dan Bingkai Media (Analisis Framing Pemberitaan Joko Widodo Sebagai Kandidat Calon Presiden Pada Koran Sindo). Jurnal Ilmiah Komunikasi Makna, 6(1), 96. https://doi.org/10.30659/jikm.6.1.96-116

Mustika, R. (2017). ANALISIS FRAMING PEMBERITAAN MEDIA ONLINE MENGENAI FRAMING ANALYSIS OF ONLINE MEDIA IN DISCLOSURE OF, 20(2), 135-148. https://doi.org/10.20422/jpk.v20i2.159

Santosa, R. (2016). Analisis Framing Pemberitaan Etnis Tionghoa dalam Media Online Republika di Bulan Februari 2016. Journal E-Komunikasi, 4(1), 1-12.

Sugiyono. (2013). Metode Penelitian Kuantitatif, Kualitatif. Bandung, Indonesia: Alfabeta.

\section{Web Site}

Azanella, L. A., \& Nugroho, R. S. (2020). Virus Korona: Penyebab, Gejala, Pencegahan, dan Kapan Harus Segera ke Dokter. Retrieved April 5, 2020, from https://Kompas.com/tren/read/2020/03/31/162000665/virus-korona--penyebab-gejalapencegahan-dan-kapan-harus-segera-ke-dokter

Harususilo, Yohanes Enggar Harususilo, Y. E. (2020). LLDikti Tetap Pantau Kegiatan Kampus Selama Pandemi Covid-19. Retrieved from https://edukasi.Kompas.com/read/2020/04/07/101712071/ldikti-tetap-pantaukegiatan-kampus-selama-pandemi-Covid-19?page =all

Niken Widya Yunita - detikNews. (2020). Penyebab, Asal Mula, dan Pencegahan Virus Korona di Indonesia. Retrieved from https://news.Detik.com/berita/d4956764/penyebab-asal-mula-dan-pencegahan-virus-korona-di-indonesia

Prof. Dr. H.M. Burhan Bungin, S.Sos, M. S. (2017). Metode Penelitian Kualitatif (kedua). Jakarta, Indonesia: Kencana.

Sakina Rakhma Diah Setiawan. (2020). Kebijakan Kerja dari Rumah Positif untuk Pegawai dan Perusahaan. Retrieved April 10, 2020, from https://money.Kompas.com/read/2020/03/18/150400026/kebijakan-kerja-dari-rumahpositif-untuk-pegawai-dan-perusahaan?page=all 
Tim detikcom - detikNews. (2020a). Kerja di Rumah Saja Bikin Volume Kendaraan Berkurang di Ibu Kota. Retrieved April 4, 2020, from https://news.Detik.com/berita/d-4956286/kerja-di-rumah-saja-bikin-volumekendaraan-berkurang-di-ibu-kota?_ga=2.199026543.1180885066.1590160681685144128.1524911125

Tim detikcom - detikNews. (2020b). Langkah Universitas Antisipasi Persebaran Korona Jadi Terbatas. Retrieved April 10, 2020, from https://news.Detik.com/berita/d4939564/langkah-universitas-antisipasi-persebaran-korona-jadi-terbatas

Widiyani, R. (2020). Latar Belakang Virus Korona, Perkembangan hingga Isu Terkini. DetikNews. Retrieved from https://news.Detik.com/berita/d-4943950/latar-belakangvirus-korona-perkembangan-hingga-isu-terkini 